\title{
Pengaruh Disiplin Kerja dan Kecerdasan Emosional Terhadap Kinerja Karyawan di Mediasi oleh Kepuasan Kerja Karyawan Pada PT. Angkasa Pura Support Bali di Kabupaten Badung
}

\author{
${ }^{1}$ Ni Putu Ayu Sintya Saraswati, ${ }^{2}$ Anak Agung Dwi Widyani, ${ }^{3}$ Ayu Stevi Rani \\ Universitas Mahasaraswati, Denpasar, Bali, Indonesia \\ Email: 1 ayustevi562@gmail.com
}

(Diterima: Feb 2021; Direvisi: Maret 2021; Dipublikasikan: Mei 2021)

\begin{abstract}
ABSTRAK
Penelitian ini bertujuan untuk mengetahui pengaruh disiplin kerja dan kecerdasan emosional terhadap kinerja karyawan secara langsung maupun tidak langsung melalui kepuasan kerja karyawan sebagai variabel mediasi pada PT Angkasa Pura Support Bali Kabupaten Badung. Pengambilan sampel dilakukan dengan teknik sampling jenuh dengan jumlah responden sebanyak 60 karyawan pada PT Angkasa Pura Support Bali di Badung. Pengolahan data menggunakan teknik analisis Structural Equation Modeling (SEM) dengan bantuan program SmartPLS 3.0 For Windows. Hasil analisis menyimpulkan bahwa disiplin kerja berpengaruh positif dan signifikan terhadap kepuasan kerja karyawan. Kecerdasan emosional berpengaruh positif dan signifikan terhadap kepuasan kerja karyawan. Disiplin kerja berpengaruh positif dan signifikan terhadap kinerja karyawan. Kecerdasan emosional berpengaruh positif tetapi tidak signifikan terhadap kinerja karyawan. Kepuasan kerja karyawan berpengaruh positif dan signifikan terhadap kinerja karyawan. Kepuasan kerja karyawan mampu memediasi pengaruh disiplin kerja dan kecerdasan emosional terhadap kinerja karyawan. Adanya keterbatasan objek penelitian yang digunakan hanya berfokus pada disiplin kerja, kecerdasan emosional dan kepuasan kerja karyawan sehingga tidak dapat menganalisis atau menjangkau lebih dalam faktor-faktor yang dapat mempengaruhi kinerja karyawan.
\end{abstract}

Kata Kunci: Disiplin Kerja, Kecerdasan Emosional, Kepuasan, Kinerja 


\section{PENDAHULUAN}

Perusahaan dalam memperoleh keuntungan melakukan kegiatan yang menggunakan faktor-faktor produksi seperti sumber daya manusia, sumber daya alam, modal, dan teknologi, sehingga memerlukan upaya-upaya untuk meningkatkan dan mengembangkan sumber daya manusia (Widyani, 2015). Mangkunegara (2015:9) menjelaskan bahwa kinerja (prestasi kerja) adalah hasil kerja secara kualitas dan kuantitas yang dicapai oleh seseorang karyawan dalam melaksanakan tugasnya sesuai dengan tanggung jawab yang diberikan kepadanya.

PT. Angkasa Pura Support adalah salah satu anak perusahaan dari PT. Angkasa Pura I (Perseo) yang bergerak dibidang penyediaan barang dan/atau jasa secara umum dan secara khusus terutama kepada Perusahaan Induk dalam rangka meningkatkan Quality Services Pengelolaan bandar udara yang modern.

Namun dalam perkembangan usahanya muncul permasalahan terkait tenaga kerja pada PT Angkasa Pura Support Bali, dimana berdasarkan hasil observasi, terdapat berbagai macam kendala utama yang timbul seperti rendahnya disiplin kerja karyawan, dimana banyak karyawan yang lupa melakukan absensi, datang terlambat, serta pulang mendahului jam kerja seharusnya, sehingga hal tersebut dihitung karyawan tidak masuk bekerja. Selain itu, terdapat permasalahan terkait kecerdasan emosional pada PT Angkasa Pura Support, diantaranya karyawan kurang mampu menahan emosi ketika menghadapi masalah dengan rekan kerja, rendahnya motivasi, rendahnya empati karyawan serta rendahnya kemampuan karyawan dalam menyampaikan pendapat pada saat rapat.

Kajian empiris oleh Nurcahya dan Sary (2018) menyimpulkan bahwa adanya pengaruh yang signifikan dari disiplin kerja terhadap kinerja karyawan bertolak belakang dengan hasil penelitian oleh Herlina (2016) yang menjelaskan bahwa disiplin kerja berpengaruh negatif dan signifikan terhadap kinerja karyawan.

Penelitian Hidayati, dkk (2013 dan Purwanti, dkk (2019) mengatakan bahwa kecerdasan emosional berpengaruh positif dan signifikan terhadap kinerja. Kecerdasan emosional yang baik akan memembuat seseorang mampu membuat keputusan yang tegas dan tepat walaupun dalam keadaan tertekan. Namun, penelitian Oktariani, dkk (2016) menjelaskan bahwa kecerdasan emosional tidak berpengaruh terhadap kinerja, kemudian dari hasil penelitian Yani dan Istiqomah (2016) menjelaskan bahwa kecerdasan emosional berpengaruh negatif dan tidak signifikan terhadap kinerja karyawan.

Kepuasan juga mempengaruhi kinerja karyawan. Penelitian Susanto (2019) menunjukkan terdapat pengaruh antara kepuasan kerja pada kinerja karyawan. Hasil penelitian ini sesuai dengan penelitian yang dilakukan Perera, dkk (2014) yang menunjukkan adanya pengaruh positif atas variabel independen kepuasan kerja terhadap variabel dependen kinerja karyawan. Hal ini berarti, meskipun kepuasan kerja karyawan mengalami peningkatan mauapun penurunan, akan memberikan banyak pengaruh 
terhadap peningkatan atau penurunan kinerja karyawan.

Perbedaan hasil penelitian satu dengan penelitian lainnya menyebabkan perlu kiranya dilakukan kajian ulang mengenai disiplin kerja dan kecerdasan emosional terhadap kinerja karyawan melalui kepuasan kerja karyawan sebagai varibael mediasi guna untuk membuktikan pengaruh masingmasing variabel tersebut terhadap secara langsung maupun tidak langsung terhadap kepuasan kerja dan kinerja karyawan.

Tujuan dari penelitian ini untuk menjawab rumusan masalah penelitian, yaitu untuk mengetahui pengaruh disiplin kerja dan kecerdasan emosional secara langsung maupun tidak langsung terhadap kepuasan kerja karyawan dan kinerja karyawan pada PT Angkasa Pura Support Bali di Kabupaten Badung.

\section{TINJAUAN PUSTAKA}

\section{Disiplin Kerja}

Sinambela

(2016:334)

menjelaskan bahwa disiplin adalah kesediaan orang yang timbul dengan kesadaran sendiri untuk mengikuti peraturan-peraturan. Hasibuan (2016:193) mengemukakan bahwa kedisiplinan adalah kesadaran dan kesediaan seseorang menaati semua peraturan perusahaan dan normanorma sosial yang berlaku.

\section{Kecerdasan Emosional}

Goleman (2013) menjelaskan bahwa kecerdasan emosi didefinisikan suatu kesadaran diri, rasa percaya diri, penguasaan diri, komitmen dan integritas dari seseorang, serta kemampuan seseorang dalam mengkomunikasikan, mempengaruhi, melakukan inisiatif perubahan dan menerimanya. Orang yang mampu mengelola emosi berarti memahami kondisi emosi dan kita harus mengkaitkannya dengan situasi yang sedang dihadapi agar memberikan dampak positif (Mangkunegara, 2015:94).

\section{Kepuasan Kerja}

Kepuasan kerja adalah tingkat perasaan menyenangkan yang diperoleh dari penilaian pekerjaan seseorang atau pengalaman kerja (Colquitt, LePine, Watson, 2011 : 105). (McShane dan Von Glinow, 2010 : 108). Kepuasan kerja adalah respon afektif atau emosional terhadap berbagai aspek dari pekerjaan seseorang (Kreitner dan Kinicki, 2010 : 170).

\section{Kinerja Karyawan}

Rivai (2014) menjelaskan bahwa kinerja merupakan perilaku nyata yang ditampilkan setiap orang sebagai prestasi kerja yang dihasilkan oleh karyawan sesuai dengan perannya dalam perusahaan, kinerja karyawan merupakan sesuatu hal yang sangat penting dalam upaya perusahaan untuk mencapai tujuannya. Kinerja karyawan yang baik merupakan langkah untuk tercapainya tujuan organisasi. Sehingga perlu diupayakan usaha untuk meningkatkan kinerja karyawan.

\section{Hipotesis}

H1 : Disiplin kerja berpengaruh positif terhadap kepuasan kerja karyawan

$\mathrm{H} 2$ : Kecerdasan emosional berpengaruh positif terhadap kepuasan kerja karyawan

H3 : $\begin{array}{rlr}\text { Disiplin kerja terhadap } \\ \text { berpengaruh positif } \\ \text { karyawan }\end{array}$ 
H4 : Kecerdasan emosional berpengaruh positif terhadap kinerja karyawan

H5 : Kepuasan kerja karyawan berpengaruh positif terhadap kinerja karyawan

H6 : Kepuasan kerja karyawan memediasi pengaruh disiplin kerja dan kecerdasan emosional terhadap kinerja karyawan

\section{METODE PENELITIAN}

Penelitian ini dilakukan pada PT Angkasa Pura Support Bali di Kabupaten Badung yang terletak di Bandar Udara I Gusti Ngurah Rai Gedung Wisti Sabha Lantai 2, Kabupaten Badung, Bali. Sampel dikumpulkan dengan menyebarkan kuesioner kepada 60 responden yang ditentukan melalui teknik sampling jenuh, sedangkan teknik analisis data dalam penelitian ini menggunakan model persamaan struktural berbasis variance atau component based structural equation model, yang dikenal dengan Partial Least Square (PLS) yang diuji melalui tahapan sebagai berikut : konseptualisasi model, menentukan model analisis algorithm, menentukan metode resampling, menggambar diagram jalur, evaluasi model, pengujian hipotesis dan pengujian pengaruh mediasi menggunakan program SmartPLS 3 (Ghozali dan Latan, 2015: 47).

Penelitian ini memfokuskan pada hubungan antara disiplin kerja, kecerdasan emosional, kepuasan kerja karyawan dan kinerja karyawan digambarkan melalui kerangka konsep berikut.

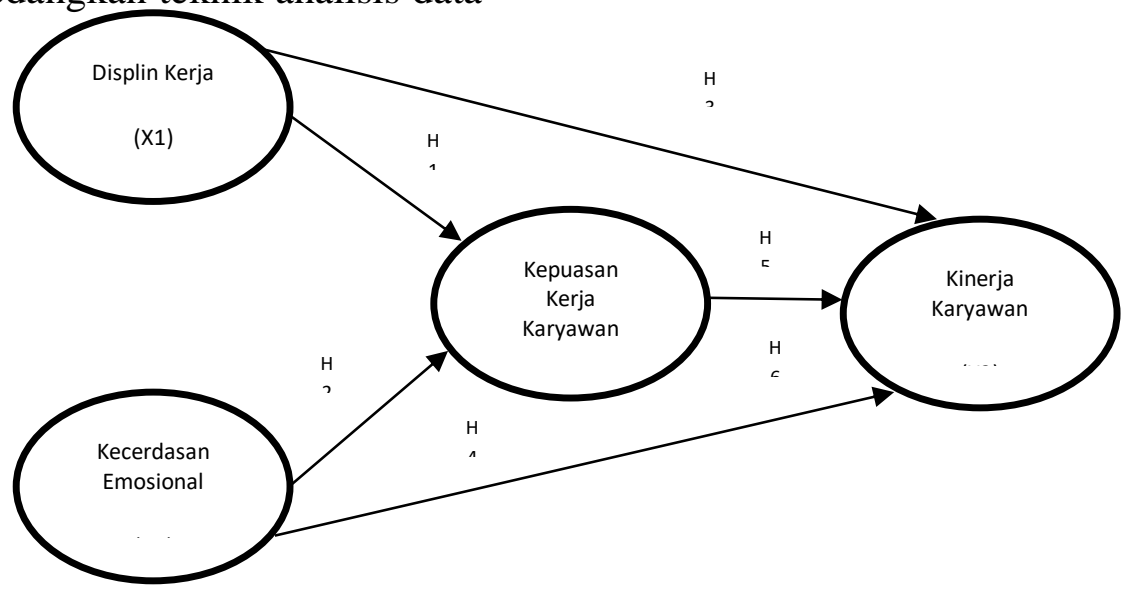

Sumber: Hasil pemikiran peneliti (2020)

Gambar 1.

Kerangka Konsep Penelitian

HASIL PENELITIAN

Evaluasi Model Pengukuran (Measurement Model/Outer Model) a) Convergent Validity

Indikator dikatakan valid, jika koefisien outer loading $>0,70$, serta nilai pvalue $<0,05$ atau signifikan pada t-statistik 1,96. Hasil perhitungan menunjukkan bahwa koefisien outer loading adalah sebagai berikut : 


\section{JENIUS}

Tabel 4.1

Hasil Perhitungan Outer Loading Indikator-Indikator untuk Variabel Disiplin Kerja, Kecerdasan Emosional, Kepuasan Kerja Karyawan dan Kinerja Karyawan

\begin{tabular}{|c|c|c|c|c|}
\hline Variabel & Indikator & $\begin{array}{l}\text { Koefisien } \\
\text { Outer } \\
\text { Loading }\end{array}$ & $P$ values & Ket. \\
\hline \multirow{5}{*}{$\begin{array}{l}\text { Disiplin Kerja } \\
\text { (X1) }\end{array}$} & Frekuensi kehadiran (X1.1) & 0.870 & 0.000 & Valid \\
\hline & Tingkat kewaspadaan $\left(\mathrm{X}_{1.2}\right.$ & 0.740 & 0.000 & Valid \\
\hline & Ketaatan pada standar kerja (X1.3) & 0.860 & 0.000 & Valid \\
\hline & Ketastan pada peraturan kerja $\{X 1.4\}$ & 0.804 & 0.000 & Valid \\
\hline & Etika kerja (X1.5) & 0.917 & 0.000 & Valid \\
\hline \multirow{3}{*}{$\begin{array}{c}\text { Kecerdasan } \\
\text { Emosional } \\
(\mathrm{X} 2)\end{array}$} & Pengendalian diri (self requlation) $(\times 2.2)$ & 0.743 & 0.000 & Valid \\
\hline & Motivasi (motivation) $(\times 2.3$ ) & 0.888 & 0.000 & Valid \\
\hline & Keterampilan social (social skills) (X2.5) & 0.831 & 0.000 & Valid \\
\hline \multirow{5}{*}{$\begin{array}{c}\text { Kepuasan Kerja } \\
\text { (Y1) }\end{array}$} & Pekerjaan itu sendiri (Y1.1) & 0.862 & 0.000 & Valid \\
\hline & Gaji (Y1.2) & 0.854 & 0.000 & Valid \\
\hline & Promosi (Y1.3) & 0.836 & 0.000 & Valid \\
\hline & Pengawasan (Y1.4) & 0.853 & 0.000 & Valid \\
\hline & Rekan kerja (Y1.5) & 0.930 & 0.000 & Valid \\
\hline \multirow{5}{*}{$\begin{array}{c}\text { Kinerja } \\
\text { Karyawan } \\
\text { (Y2) }\end{array}$} & Kuantitas Pekerjaan [Y2.1) & 0.791 & 0.000 & Valid \\
\hline & Kualitas Pekerjaan (Y2.2) & 0.852 & 0.000 & Valid \\
\hline & Waktu Pekerjaan (Y2.3) & 0.803 & 0.000 & Valid \\
\hline & Efektifitas (Y2.4) & 0.924 & 0.000 & Valid \\
\hline & Cara Melakukan Pekerjaan (Y2.5] & 0.929 & 0.000 & Valid \\
\hline
\end{tabular}

Sumber: Olah Data, 2020

\section{b) Discriminant Validity}

Tabe1 4.2

Hasil Perhitungan Cross Loading

\begin{tabular}{|c|c|c|c|c|}
\hline & Disiplin Kerja & Kecerdasan Emosional & Kepuasan Kerja Karyawan & Kinerja Karyawan \\
\hline X1.1 & $\mathbf{0 . 8 7 0}$ & 0.443 & 0.405 & 0.473 \\
\hline $\mathbf{X 1 . 2}$ & $\mathbf{0 . 7 4 0}$ & 0.451 & 0.281 & 0.503 \\
\hline $\mathbf{X 1 . 3}$ & $\mathbf{0 . 8 6 0}$ & 0.444 & 0.619 & 0.728 \\
\hline $\mathbf{X 1 . 4}$ & $\mathbf{0 . 8 0 4}$ & 0.346 & 0.335 & 0.446 \\
\hline $\mathbf{X 1 . 5}$ & $\mathbf{0 . 8 2 3}$ & 0.452 & 0.546 & 0.649 \\
\hline X2.2 & 0.241 & $\mathbf{0 . 7 4 3}$ & 0.231 & 0.174 \\
\hline X2.3 & 0.520 & $\mathbf{0 . 8 8 8}$ & 0.473 & 0.424 \\
\hline X2.5 & 0.419 & $\mathbf{0 . 8 3 1}$ & 0.574 & 0.282 \\
\hline Y1.1 & 0.557 & 0.479 & $\mathbf{0 . 8 6 2}$ & 0.599 \\
\hline Y1.2 & 0.457 & 0.442 & $\mathbf{0 . 8 5 4}$ & 0.478 \\
\hline Y1.3 & 0.444 & 0.515 & $\mathbf{0 . 8 3 6}$ & 0.552 \\
\hline Y1.4 & 0.382 & 0.395 & $\mathbf{0 . 8 5 3}$ & 0.448 \\
\hline Y1.5 & 0.517 & 0.572 & $\mathbf{0 . 9 3 0}$ & 0.586 \\
\hline Y2.1 & 0.418 & 0.204 & 0.377 & $\mathbf{0 . 7 9 1}$ \\
\hline Y2.2 & 0.489 & 0.392 & 0.493 & $\mathbf{0 . 8 5 2}$ \\
\hline Y2.3 & 0.644 & 0.303 & 0.504 & $\mathbf{0 . 8 0 3}$ \\
\hline Y2.4 & 0.659 & 0.407 & 0.626 & $\mathbf{0 . 9 2 4}$ \\
\hline Y2.5 & 0.687 & 0.316 & 0.615 & $\mathbf{0 . 9 2 9}$ \\
\hline
\end{tabular}

Sumber: Olah Data, 2020

Hasil menjelaskan bahwa loading factor mampu memprediksi indikator pada blok mereka lebih c) Reliability baik dibandingkan dengan indikator di blok yang lain.

Tabel 4.3

Hasil Perhitungan Composite Reliability dan Cronbach Alpha

\begin{tabular}{|l|c|c|c|}
\hline \multicolumn{1}{|c|}{ Variabel } & $\begin{array}{c}\text { Composite } \\
\text { Reliability }\end{array}$ & Cronbach Alpha & Keterangan \\
\hline Disiplin Kerja & 0,923 & 0,896 & Reliabel \\
\hline Kecerdasan Emosional & 0,862 & 0,810 & Reliabel \\
\hline Kepuasan Kerja Karyawan & 0,938 & 0,918 & Reliabel \\
\hline Kinerja Karyawan & 0,935 & 0,913 & Reliabel \\
\hline
\end{tabular}

Sumber : Data Diolah, 2020 
Hasil perhitungan composite reliability dan cronbach alpha, menunjukkan bahwa model penelitian ini adalah reliabel.

\section{Evaluasi Model Struktural} (Structural Model/Inner Model)

\section{a) Evaluasi Model Struktural Melalui $R$-Square $\left(R^{2}\right)$}

Tabel 4.4

Hasil Perhitungan $R$-Square dan $A V E$

\begin{tabular}{|c|c|c|}
\hline Variabel & $R$-Square & $A V E$ \\
\hline $\begin{array}{ll}\text { Kepuasan } & \text { Kerja } \\
\text { Karyawan } & \\
\end{array}$ & 0,392 & 0,753 \\
\hline Kinerja Karyawan & 0,567 & 0,743 \\
\hline
\end{tabular}

Sumber : Data Diolah, 2020

Nilai $R^{2}{ }_{1}$ adalah sebesar 0,408 , yang artinya kepuasan kerja karyawan dipengaruhi oleh disiplin kerja dan kecerdasan emosional sebesar $40,8 \%$, sedangkan sisanya $59,2 \%$ adalah faktor lain diluar model penelitian. Nilai $R^{2}$ sebesar 0,408 tergolong model yang moderat.

Nilai $R_{2}^{2}$ sebesar 0,566 , artinya $56,6 \%$ kinerja karyawan dipengaruhi oleh disiplin kerja, kecerdasan emosional dan kepuasan kerja karyawan, sisanya sebesar 43,4\% adalah faktor lain di luar model penelitian. Nilai $R^{2}$ sebesar 0,566 termasuk katagori moderat.

\section{b) Evaluasi Model Struktural melalui $Q$-Square Predictive Relevance $\left(Q^{2}\right)$}

Hasil perhitungan $Q$-Square Predictive Relevance $\left(Q^{2}\right)$ sebagai berikut:

$$
\begin{aligned}
Q^{2} & =1-\left(1-\mathrm{R}^{2}\right)\left(1-\mathrm{R}^{2}{ }_{2}\right) \\
& =1-(1-0,392)(1-0,567) \\
& =1-(0,608)(0,433) \\
& =1-(0,263264) \\
& =0,7367 \text { dibulatkan menjadi } \\
& 0,738
\end{aligned}
$$

Hasil perhitungan $Q^{2}$ sebesar 0,738 menunjukkan bahwa $73,8 \%$ model dapat dijelaskan melalui hubungan antar variabel dalam model penelitian, sedangkan sisanya $26,2 \%$ adalah faktor lain diluar model penelitian, sedangkan model tergolong dalam kategori kuat.

c) Evaluasi Model Struktural melalui Goodness of Fit (GoF)

Hasil pengukuran kuat lemahnya model berdasarkan Goodness of Fit (GoF), adalah sebagai berikut :

$\mathrm{GoF}=\sqrt{\left(\mathrm{AVE} \times \mathrm{R}^{2}\right)}$

$\mathrm{GoF}=\sqrt{[\{(0,706+0,599+0,753+0,743}$

)$/ 4\}$

$$
\sqrt{\mathrm{x}\{(0,392+0,567) / 2\}]}
$$

$\mathrm{GoF}=\sqrt{[\{2,801 / 4\} \times\{0,825 / 2\}]}$

$\mathrm{GoF}=\sqrt{0,70025 \times 0,413}$

$\mathrm{GoF}=\sqrt{0,28920325}$

$\mathrm{GoF}=0,538$

Hasil perhitungan GoF di atas, menunjukkan nilainya sebesar 0,538 , maka mengacu pada kriteria kuat lemahnya model pengukuran melalui Goodness of Fit (GoF) tergolong ke dalam model yang kuat. 


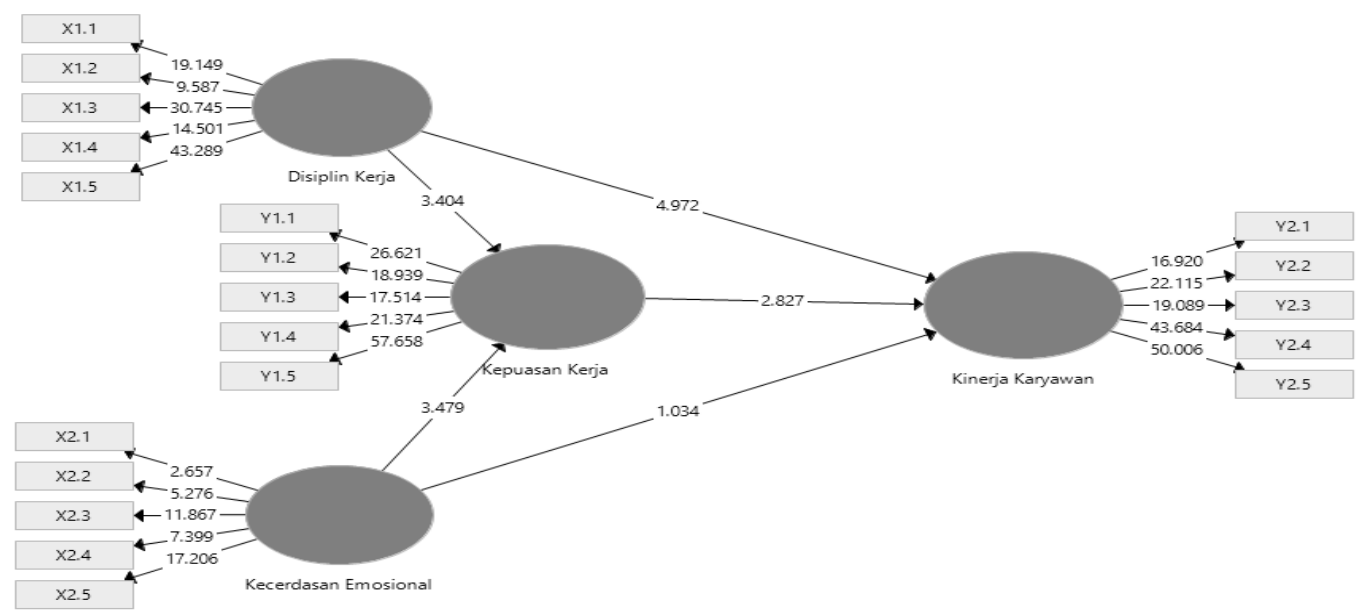

Sumber : Data Diolah, 2020

Gambar 2

Diagram Path Hubungan Antara Disiplin Kerja, Kecerdasan Emosional, Kepuasan

Kerja Karyawan dan Kinerja Karyawan

Tabel 4.5

Hubungan Antara Disiplin Kerja, Kecerdasan Emosional, Kepuasan Kerja Karyawan dan Kinerja Karyawan

\begin{tabular}{|l|c|c|c|c|}
\hline \multicolumn{1}{|c|}{ Hubungan Antar Variabel } & $\begin{array}{c}\text { Koefisien } \\
\text { Jalur }\end{array}$ & $\begin{array}{c}T \\
\text { Statistics }\end{array}$ & $\begin{array}{c}\boldsymbol{P} \\
\text { Values }\end{array}$ & Keterangan \\
\hline Disiplin Kerja (X1) -> Kepuasan Kerja Karyawan (Y1) & 0.377 & 3.404 & 0.001 & Signifikan \\
\hline $\begin{array}{l}\text { Kecerdasan Emosional (X2) -> Kepuasan Kerja } \\
\text { Karyawan (Y1) }\end{array}$ & 0.370 & 3.479 & 0.001 & Signifikan \\
\hline Disiplin Kerja (X1) - > Kinerja Karyawan (Y2) & 0.527 & 4.972 & 0.000 & Signifikan \\
\hline Kecerdasan Emosional (X2) -> Kinerja Karyawan (Y2) & 0.118 & 1.034 & 0.302 & $\begin{array}{c}\text { Tidak } \\
\text { Signifikan }\end{array}$ \\
\hline Kepuasan Kerja Karyawan (Y1) -> Kinerja Karyawan (Y2) & 0.395 & 2.827 & 0.005 & Signifikan \\
\hline
\end{tabular}

Sumber: Data Diolah, 2020

\section{Pengaruh Disiplin Kerja Terhadap Kepuasan Kerja Karyawan}

Koefisien jalur antara disiplin kerja dengan kepuasan kerja karyawan bernilai positif sebesar 0,377 dengan koefisien t-statistik sebesar 3,404 > t-tabel 1,96, dan nilai signifikansi sebesar $0,001<0,05$. Hasil pengujian ini membuktikan hipotesis $1\left(\mathrm{H}_{1}\right)$, yang menyatakan bahwa disiplin kerja berpengaruh positif dan signifikan terhadap kepuasan kerja karyawan menjelaskan bahwa meningkatnya disiplin kerja maka akan diikuti oleh meningkatnya kepuasan kerja karyawan.

Karyawan yang memiliki ciri perilaku pekerja yang puas adalah mereka mempunyai motivasi untuk berkerja yang tinggi, mereka lebih senang dalam melakukan pekerjaannya, sedangkan ciri pekerja yang kurang puas adalah mereka yang malas berangkat ke tempat bekerja dan malas dengan pekerjaan dan tidak puas.

Hasil penelitian ini sejalan dengan penelitian Simoes, dkk (2017), Nugrahaningsih dan Julaela (2017), Supriyadi (2017), Lusigita 
(2017) dan Saputri (2019) yang menunjukkan bahwa disiplin diri berpengaruh positif signifikan terhadap kepuasan kerja karyawan.

\section{Pengaruh Kecerdasan Emosional Terhadap Kepuasan Kerja Karyawan}

Koefisien jalur dari kecerdasan emosional ke kepuasan kerja karyawan memiliki nilai yang positif sebesar 0,370, dengan koefisien tstatistik sebesar 3,479>t-tabel 1,96, dan nilai signifikansi sebesar $0,001<$ 0,05. Hasil pengujian ini membuktikan bahwa hipotesis 2 $\left(\mathrm{H}_{2}\right)$, yang menyatakan bahwa kecerdasan emosional berpengaruh positif dan signifikan terhadap kepuasan kerja karyawan dapat diterima, artinya semakin tinggi kecerdasan emosional karyawan maka maka kepuasan kerja karyawan juga ikut meningkat.

Kecerdasan emosional merupakan suatu kemampuan untuk mendengarkan bisikan emosi, dan menjadikannya sebagai sumber informasi yang sangat penting untuk memahami diri sendiri dan orang lain demi mencapai tujuan (Sinaga, 2016). Karyawan yang merasa dapat menunjukkan kemampuannya dalam bekerja dan mampu mengekspresikan emosi dirinya akan merasa puas (Mandala, 2018).

Berdasarkan kajian empiris yang dilakukan oleh Zama (2017), Parawitha dan Gorda (2017), Holis (2017), Dewi (2019), serta Vitaloka dan Netra (2019) menunjukkan bahwa secara parsial variabel kecerdasan emosional berpengaruh positif dan signifikan terhadap kepuasan kerja.

\section{Pengaruh Disiplin Kerja Terhadap Kinerja Karyawan}

Koefisien jalur dari variabel disiplin kerja ke kinerja karyawan bernilai positif sebesar 0,527, dengan koefisien t-statistik sebesar 4,972 > ttabel 1,96, dan nilai signifikansi sebesar $0,000<0,05$. Hasil pengujian ini menunjukkan bahwa hipotesis 3 $\left(\mathrm{H}_{3}\right)$, yang menyatakan bahwa disiplin kerja kerja berpengaruh positif dan signifikan terhadap kinerja karyawan, artinya semakin tinggi disiplin kerja karyawan maka maka kinerja karyawan akan meningkat.

Sinambela (2016:243) tujuan utama tindakan pendisiplinan adalah memastikan bahwa perilaku-perilaku karyawan konsisten dengan aturanaturan yang ditetapkan oleh organisasi. Berbagai aturan yang disusun oleh organisasi adalah tuntunan untuk mencapai tujuan organisasi yang ditetapkan.

Penelitian Purwanti, dkk (2019) dan Rifaldi (2019) menjelaskan disiplin kerja memiliki pengaruh yang positif dan signifikan terhadap kinerja karyawan, demikian pula hasil penelitian Nugroho (2020), dan Waluyo (2020) menyimpulkan bahwa disiplin kerja berpengaruh positif dan signifikan terhadap kinerja karyawan.

\section{Pengaruh Kecerdasan Emosional Terhadap Kinerja Karyawan}

Koefisien jalur dari kecerdasan emosional ke kinerja karyawan yang bernilai positif sebesar 0,118 , namun nilai koefisien t-statistik sebesar $1,034<$ t-tabel 1,96, dan nilai signifikansi sebesar 0,302>0,05. Hasil pengujian ini membuktikan bahwa hipotesis $4 \quad\left(\mathrm{H}_{4}\right)$, yang 
menyatakan bahwa kepuasan kerja karyawan berpengaruh positif dan signifikan terhadap kinerja karyawan ditolak, artinya kecerdasan emosional dalam penelitian ini tidak berpengaruh terhadap peningkatan kinerja karyawan.

Effendi (2020) menyebutkan bahwa kecerdasan emosional memiliki dampak negatif bagi produktivitas seseorang. Orangorang dengan kecerdasan emosional yang tinggi memiliki empati besar kepada orang lain dan biasanya lebih perasa, namun hal ini membuat mereka cenderung lebih sulit memberikan komentar negatif kepada orang lain. Saat menghadapi kritik, mereka yang mempunyai kecerdasan emosional tinggi mungkin tidak akan mengenalinya sebagai komentar negatif. Mereka kadang terlalu tenang dan positif, tanpa menyadari bahwa orang lain mengharapkan perubahan dari dirinya. Mereka yang mempunyai kecerdasan emosional terlalu tinggi biasanya lebih suka bermain aman tanpa banyak mengambil risiko. Hal ini disebabkan karena mereka memiliki kendali diri yang besar, dan memastikan segalanya teratur dan tidak ingin terburu-buru. Semakin tinggi kecerdasan emosional seseorang, maka semakin besar pula keinginan untuk mengontrol diri. Kendali diri yang berlebihan terkadang bisa membuat mereka takut mengambil risiko yang penting. Padahal, ini merupakan perilaku yang membuat sulit berkembang dalam pekerjaan, hubungan sosial, dan aspek kehidupan lainnya.

Hasil penelitian ini sejalan dengan penelitian Hidayati, dkk (2013) kecerdasan emosional tidak berpengaruh signifikan terhadap kepuasan kerja dan kinerja, penelitian Impiansi, dkk (2014) juga menjelaskan bahwa variabel kecerdasan emosi tidak berpengaruh terhadap kinerja, serta mendukung hasil penelitian Oktariani (2016) dimana berdasarkan hasil uji diketahui bahwa kecerdasan emosional tidak berpengaruh terhadap kinerja karyawan.

\section{Pengaruh Kepuasan Kerja Karyawan Terhadap Kinerja Karyawan}

Koefisien jalur dari variabel disiplin kerja ke kinerja karyawan bernilai positif sebesar 0,395 dengan koefisien t-statistik sebesar 2,827 > ttabel 1,96, dan nilai signifikansi sebesar $0,005<0,05$. Hasil pengujian ini menunjukkan bahwa hipotesis 5 $\left(\mathrm{H}_{5}\right)$, yang menyatakan bahwa kepuasan kerja karyawan berpengaruh positif dan signifikan terhadap kinerja karyawan. Hasil penelitian menjelaskan bahwa semakin tinggi kepuasan kerja karyawan maka kinerja karyawan akan meningkat.

Kepuasan kerja adalah salah satu masalah yang penting dan banyak diteliti dalam bidang perilaku organisasi (Kowey, 2016), maka dari itu organisasi dengan lebih banyak pekerja yang lebih puas cenderung kinerjanya lebih efektif dibandingkan organisasi yang lebih rendah kepuasan kerja karyawannya.

Hasil penelitian ini sejalan dengan hasil kajian empiris oleh Nasution, dkk (2018), Susanto (2019), dan Simanjuntak (2020) menjelaskan bahwa kepuasan kerja secara statistik memiliki pengaruh yang positif dan signifikan terhadap 
kinerja karyawan, sehingga kepuasan kerja dapat dikatakan erat kaitannya dengan upaya peningkatan kinerja karyawan dalam organisasi.

\section{Pengaruh Disiplin Kerja dan Kecerdasan Emosional terhadap Kinerja Karyawan Melalui Kepuasan Kerja Karyawan}

Tabel 4.6

Hasil Perhitungan Total Indirect Effect

\begin{tabular}{|c|c|c|c|c|}
\hline Hubungan Antar Variabel & $\begin{array}{c}\text { Koefisien } \\
\text { Jalur }\end{array}$ & $\begin{array}{c}T \\
\text { Statistics }\end{array}$ & P Values & Keterangan \\
\hline 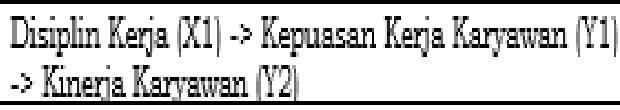 & 0.149 & 2.388 & 0.017 & Signifilkan \\
\hline 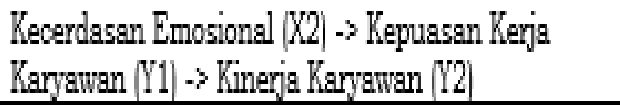 & 0.146 & 2.072 & 0.042 & Signifikan \\
\hline
\end{tabular}

Sumber: Data Diolah, 2020

Koefisien jalur antara disiplin kerja terhadap kinerja karyawan melalui kepuasan kerja memiliki nilai yang positif sebesar 0,149 dengan koefisien t-statistik sebesar 2,388 > ttabel 1,96 dan nilai signifikansi adalah sebesar $0,017<0,05$, sedangkan koefisien jalur antara kecerdasan emosional terhadap kinerja karyawan melalui kepuasan kerja memiliki nilai yang positif sebesar 0,146 dengan koefisien $t$ statistik sebesar 2,072 > t-tabel 1,96 dan nilai signifikansi adalah sebesar $0,042<0,05$. Hasil pengujian ini membuktikan hipotesis $6\left(\mathrm{H}_{6}\right)$, yang menyatakan kepuasan kerja karyawan memediasi pengaruh disiplin kerja dan kecerdasan emosional terhadap kinerja karyawan dapat diterima.

Hasil penelitian Riski dan Riana (2018) menjelaskan bahwa kepuasan kerja mampu memediasi pengaruh disiplin kerja dan kecerdasan emosional terhadap kinerja karyawan, artinya melalui kepuasan kerja karyawan, akan mampu untuk meningkatkan disiplin kerja dan kecerdasan emosional guna meningkatkan kinerja karyawan.

\section{KESIMPULAN DAN SARAN}

\section{A. Kesimpulan}

1. Disiplin kerja berpengaruh positif dan signifikan terhadap kepuasan kerja karyawan. Hasil penelitian ini memberikan indikasi bahwa peningkatan disiplin kerja dapat meningkatkan kepuasan kerja karyawan pada PT Angkasa Pura Support Bali di Kabupaten Badung.

2. Kecerdasan emosional berpengaruh positif dan signifikan terhadap kepuasan kerja karyawan. Hasil penelitian ini memberikan indikasi bahwa peningkatan kecerdasan emosional dapat meningkatkan kepuasan kerja karyawan pada PT Angkasa Pura Support Bali di Kabupaten Badung.

3. Disiplin kerja berpengaruh positif dan signifikan terhadap kinerja karyawan. Hasil penelitian ini memberikan indikasi bahwa peningkatan disiplin kerja dapat meningkatkan kinerja 
karyawan pada PT Angkasa Pura Support Bali di Kabupaten Badung.

4. Kecerdasan emosional berpengaruh positif namun tidak signifikan terhadap kinerja karyawan. Hasil penelitian ini menunjukkan bahwa meningkatnya kecerdasan emosional pada karyawan PT Angkasa Pura Support Bali di Kabupaten Badung tidak berpengaruh terhadap meningkatnya kinerja karyawan.

5. Kepuasan kerja karyawan berpengaruh positif dan signifikan terhadap kinerja karyawan. Hasil penelitian ini memberikan indikasi bahwa meningkatnya kepuasan kerja karyawan maka akan dapat meningkatkan kinerja karyawan pada PT Angkasa Pura Support Bali di Kabupaten Badung.

6. Kepuasan kerja karyawan mampu memediasi pengaruh disiplin kerja dan kecerdasan emosional terhadap kinerja karyawan. Hal ini memberikan indikasi bahwa kepuasan kerja karyawan harus menjadi perhatian dalam meningkatkan kinerja karyawan pada PT Angkasa Pura Support Bali di Kabupaten Badung.

\section{B. Saran}

Usaha yang dapat dilakukan
dalam meningkatkan kinerja karyawan, di antaranya meningkatkan indikator disiplin kerja dengan ratarata terendah yaitu ketaatan pada standar kerja, mengelola kecerdasan emosional karyawan dengan meningkatkan motivasi (motivation), meningkatkan pengawasan guna meningkatkan kepuasan kerja karyawan.

\section{DAFTAR PUSTAKA}

Affandi, A., Sarwani, A. S., Erlangga, H., Siagian, A. O., Purwanto, A., Effendy, A. A., .. \& Wahyitno, C. D. M. (2020). Optimization of MSMEs Empowerment in Facing Competition in the Global Market during the COVID-19 Pandemic Time. Systematic Reviews in Pharmacy, 11(11), 1506-1515.

Ardana, I Komang, Wayan Mudiartha Utama dan Wayan Mujiati, (2012). Manajemen Sumber Daya Manusia, Penerbit Graha Ilmu, Yogyakarta.

Colquitt, J. A., Lepine, A. J., \& Wesson, J. M. (2011). Organizational Behavior. New York: Mc. Graw Hill.

Dessler, G. (2015). Manajemen Sumber Daya Manusia. Jakarta: Salemba Empat. Harianja.

Edision, Emron dkk, (2016), Manajemen Sumber Daya Manusia, Alfabeta, Bandung.

Ghozali, Imam, Hengky Latan. (2015). Konsep, Teknik, Aplikasi Menggunakan. Smart PLS 3.0 Untuk Penelitian Empiris. BP Undip. Semarang.

Goleman, Daniel. (2015). Emotional Intelligence : Kecerdasan emosional mengapa EI lebih penting daripada IQ, Jakarta: PT. Gramedia Pustaka

Handoko, T.H. (2014). Manajemen Personalia dan Sumber Daya Manusia. BPFE, Yogyakarta. 
Hartanto, Hidayah, S., Harnoto. (2017). Peningkatan Kinerja Pegawai Melalui Kecerdasan Emosional, Kecerdasan Spiritual, dan Kepuasan Kerja Pegawai di Kecamatan Gunungpati Kota Semarang. Jurnal Ekonomi Manajemen dan Akuntansi. No. 43 / Th. XXIV / Oktober 2017

Hasibuan, M.S.P. (2016), Manajemen Sumber Daya Manusia, Edisi Revisi, Penerbit PT. Bumi Aksara, Jakarta.

Hidayati, I.N., Setiawan, M., Solimun. (2013). Kecerdasan Emosional dan Kecerdasan Spiritual Pengaruhnya terhadap Kepuasan Kerja dan Kinerja Karyawan (Studi di Lembaga Penjaminan Mutu Pendidikan (LPMP) Nusa Tenggara Barat). Jurnal Aplikasi Manajemen. Vol. 11 No. 4 Desember 2013.

Kristine, Erline. (2017). Pengaruh Kepuasan kerja dan Komitmen Organisasi terhadap Kinerja Melalui Motivasi Kerja Pegawai Alih Daya (Outsourching) Di PT. Mitra Karya Jaya Sentosa. Jurnal Eksekutif. Volume 14 No. 2 Desember 2017

Kustini, E., \& Sari, N. (2020). Pengaruh Pelatihan Dan Disiplin Kerja Terhadap Produktivitas Kerja Karyawan Pada PT. Bumen Redja AbadiBSD. JENIUS (Jurnal Ilmiah Manajemen Sumber Daya Manusia), 3(3), 303-311.

Lansart, T.A., Tewal, B., Dotulong. L.O. (2019). Pengaruh Kecerdasan EMosional, Dukungan Organisasi dan
Keadilan Organisasional terhadap Kinerja Pegawai di Biro Organisasi Sekretariat Daerah Pemerintah Provinsi Sulawesi Utara. Jurnal EMBA. Vol.7 No.4 Oktober 2019, Hal. 5593-5602. ISSN 2303-1174

Lusigita. K. (2017). Pengaruh Kepemimpinan dan Disiplin Kerja Trhadap Kepausan Kerja dan Kinerja Pegawai Negeri Sipil pada Dinas Sosial dan Tenaga Kerja Kabupaten Badung. JAGADHITA: Jurnal Ekonomi \& Bisnis, Vol. 4, No 1. Maret 2017, Hal 27-37. Available Online at http://ejournal.warmadewa.ac.i d/index.php/jret.DOI:10.22225 /JJ.4.1.209.27-37

Mahdani, F., Hafasnuddin, Adam, M. (2017). Pengaruh Motivasi, Kecerdasan Emosional dan Keadilan Organisasi terhadap Kepausan Kerja serta Implikasinya pada Kinerja Karyawan (Studi pada Kanwil PT Bank Rakyat Indonesia (PERSERO) Tbk. Banda Aceh). Jurnal Magister Manajemen Fakultas Ekonomi dan Bisnis Unsyiah pp. 1- 15. Volume 1, No. 1, September 2017 - 1. ISSN 2302-0199.

Mandala, E.A., Dihan, F.N. (2018). Pengaruh Kecerdasan Emosional dan Kecerdasam Spiritual pada Kepuasan Kerja yang Berdampak terhadap Kinerja Karyawan PT Madu Baru Bantul, Yogyakarta. Jurnal Kajian Bisnis. VOL. 26, NO. 1, 2018, 13 - 29

Mangkunegara, A.P. (2015). Evaluasi Kinerja SDM, Penerbit Refika Aditama, Bandung 
Muslimat, A., Ab Wahid, H., \& Erlangga, H. (2020). Effect Of Organizational Commitment On The Sustainability Performance Of Indonesian Industries. PalArch's Journal of Archaeology

Egypt/Egyptology, 17(6), 83308347.

Nurjaya, N., Erlangga, H., Hong, L. Z., \& Wijayanti, K. D. (2020). The Effect of Work Stress and Work Conflict on Employees Turnover Intention In Middle Small Micro Enterprises (MSMEs) In South Tangerang Region. International Journal of Educational Administration, Management, and Leadership, 51-62.

Nurjaya, N., Sunarsi, D., Effendy, A. A., Teriyan, A., \& Gunartin, G. (2021). Pengaruh Etos Kerja Dan Disiplin Kerja Terhadap Kinerja Pegawai Pada Dinas Kehutanan Dan Perkebunan Kota Bogor. JENIUS (Jurnal Ilmiah Manajemen Sumber Daya Manusia), 4(2), 172-184.

Rachmelya, E., Suryani, A. (2017).

Pengaruh Kecerdasan Emosional dan Stres Kerja terhadap Kepuasan Kerja dan Dampaknya terhadap Komitmen Organisasi Frontliner Bakti PT Bank Central Asia Tbk KCU Jambi. Ekonomis : Jurnal of Economics and Business Vol.1 No.1 September 2017

Rahmat, A. (2017). Kecerdasan Emosional dan Dampaknya terhadap Stres Kerja dan Kinerja Karyawan Muhammad Rasyid Abdillah. Jurnal Ekonomi dan Bisnis Islam.
Volume 2, Nomor 1, JanuariJuni 2017

Rivai, V. (2014), Manajemen Sumber Daya Manusia Untuk Perusahaan, Dari Teori ke Praktik, Penerbit PT. Rajagrafindo Persada, Jakarta. Saraswati, N.P.A.S dan Ribek, P.K. (2018). Pengaruh Keadilan Organisasi, Kepuasan Kerja dan Organizationl Citizenship Behavior terhadap Turnover Intention karyawan pada Negari Coffee Luwak. Juima Vol. 8 No. 1, Maret 2018

Sedarmayanti. (2015). Sumber Daya Manusia dan Produktivitas Kerja. Bandung: Mandar Maju Setyaningrum, R., Utami, H.N., Ruhana, K. (2016). Pengaruh Kecerdasan Emosional terhadap Kinerja Studi Pada Karyawan PT. Jasa Raharja Cabang Jawa Timur. Jurnal Administrasi Bisnis. VOL 36, NO 1 (2016)

Siagian, S.P (2016), Manajemen Sumber Daya Manusia, Penerbit Bumi Aksara, Jakarta.

Simamora. H. (2013). Paduan Perilaku Organisasi. Jakarta: Gramedia.

Sinaga, H. (2016). Pengaruh Disiplin, Motivasi dan Kecerdasan Emosional terhadap Prestasi Kerja Karyawan pada Depot FP LPG Pertamina Tandem. Jurnal Manajemen Tools. Vol. 6 No 1. Juni 2016 ISSN : 2088-3145

Sinambela. Lijan Poltak. (2016). Manajemen Sumber Daya Manusia: Membangun. Tim Kerja yang Solid untuk Meningkatka Kinerja, Jakarta: Bumi Aksara 
Stephen P. Robbins dan Timothy A. Judge, (2018), Perilaku Organisasi Organizational Behavior, Penerbit Salemba Empat, Jakarta.

Sukmawati, Gani, N. (2014). Pengaruh Kecerdasan Emosional, Kepuasan Kerja, dan Komitmen Organisasi Terhadap Kinerja Karyawan pada Koperasi Karyawan PT. Telkom Siporennu Makassar. Jurnal Manajemen dan Akuntansi Volume 3, Nomor 3, Desember 2014. p ISSN 02164930

Sulastri, L., Novitasari, D., Rahmaningtyas, W., Sulaeman, R., \& Erlangga, H. (2020). The Role of Decision Support System and Risk Management Using Social Media Promotion. International Journal of Psychosocial Rehabilitation, 24(1).

Supardi dan Syaiful Anwar, (2014), Dasar-Dasar Perilaku Organisasi, Penerbit UII Press, Yogyakarta.

Supriyadi, M.F., Priadana, S., Setia, B.I. (2017). Kompensasi dab Disiplin Kerja terhadap Kepuasan Kerja Karyawan di Restoran Kompoeng Daun. Jurnal Riset Bisnis dan Manajemen (JRBM). Volume 10, No 2, Agustus 2017, Hal. 24-33. ISSN 1979-0600 (print) 2580-9539 (online)

Sutrisno. E. (2016). Manajemen Sumber Daya Manusia.
Cetakan ke-8. Jakarta : Prenada Media Group.

Suwanto, S. (2019). Pengaruh Disiplin Kerja Dan Motivasi Kerja Terhadap Kinerja Karyawan Pada Rumah Sakit Umum Tangerang Selatan. JENIUS (Jurnal Ilmiah Manajemen Sumber Daya Manusia), 3(1), 16-23.

Wibowo, (2016). Perilaku Dalam Organisasi, Penerbit. PT. Rajagrafindo Persada, Jakarta.

Widyani, A.A.D, Saraswati, N.P.A.S., Wijaya, I.N.B. (2019). The Mediating Role of Turnover Intention on The Relationship Between Job Satisfaction and Employee Performance: Evidance From PT. Angkasa Angkasa Pura Suport di Kabupaten Badung Employees. International Journal of Applied Business \& International Management, Vol. 4 No. 3 (2019) E-ISSN: 2621-2862

Wirawan, (2015). Evaluasi Kinerja Sumber Daya Manusia (Teori, Aplikasi, dan. Penelitian). Jakarta: Salemba Empat.

Zama, F.G. (2017). Pengaruh Kecerdasan Emosional dan Lingkungan Kerja terhadap Kepuasan Kerja pada Karyawan PT Reksa Finance Cabang Lampung. Skripsi. Fakultas Ekonomi dan Bisnis Universitas Lampung. 